\title{
Effect of Coenzyme Q10 as an Antioxidant Added to Semen Extender During Cryopreservation of Buffalo and Cattle Semen
}

Saeed, A. M.; H. A. El-Nagar; W. M. Wafa and Y. S. Hussein

Animal Production Research Institute, Agricultural Research Center, Dokki, Giza, Egypt.

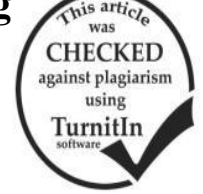

\section{ABSTRACT}

This study was conducted to assess the influence of supplementing Tris-extender with Coenzyme Q10 (COQ10) as an antioxidant on sperm characteristics of Egyptian buffalo and cattle. This study was carried out at Animal Production Research Station, El-Gemmezah, belonging to Animal Production Research Institute, Egypt. Five sexually mature buffalo (4 y and $400-$ $450 \mathrm{~kg}$ ) and Friesian (3 y and 350-400 kg) bulls were used in this study. Semen was collected twice weekly for five successive weeks. Only ejaculates with $\geq 70 \%$ mass motility were pooled and diluted at $37^{\circ} \mathrm{C}$ with Tris-extender containing 0,20 and $30 \mu \mathrm{M}$ of CoQ10 in T1, T2 and T3, respectively. Equilibration period was at $5^{\circ} \mathrm{C}$ for $4 \mathrm{~h}$ and semen was packed in $0.25 \mathrm{ml} \mathrm{French}$ straws frozen in liquid nitrogen $-196^{\circ} \mathrm{C}$. Stored straws were thawed individually at $37^{\circ} \mathrm{C}$ for $30 \mathrm{~s}$. Semen was evaluated for sperm characteristics including percentages of progressive motility, livability, abnormality, curled tail and acrosomal damage of spermatozoa. Enzymatic activity of AST, ALT and LDH was determined in seminal plasma of post-thawed semen. Results showed that there were no species differences in all sperm characteristics studied, except for increasing $(\mathrm{P}<0.05)$ percentage of abnormality and damage acrosome spermatozoa in post-thawed semen of cattle compared with buffalo bulls. All sperm characteristics were improved $(\mathrm{P}<0.05)$ by $30 \mu \mathrm{M}$ COQ10 supplementation $\mathrm{T} 3$ in post-diluted, post-equilibrated and post thawed semen as compared to control without supplementation $\mathrm{T} 1$ in buffalo and cattle semen. Activity of all enzymes reduced $(\mathrm{P}<0.05)$ in seminal plasma of both species. In conclusion, CoQ10, as antioxidant, at a level of $30 \mu \mathrm{M}$ in Tris-extender is able to enhance most sperm characteristics including mobility, livability, plasma membrane integrity, with decreasing sperm abnormalities and it has strong protective power against acrosomal damage of buffalo and cattle spermatozoa.

Keywords: Cattle, buffalo, semen, coenzyme Q10, membrane integrity, enzyme activity.

\section{INTRODUCTION}

The production potential of livestock can be increased by genetic improvement using one of the modern ways of breed improvement, e.g. artificial insemination (AI). Cryopreservation of sperm is an essential tool which offers many advantages to the livestock industry (Bucak et al., 2009). AI makes the dissemination of genetic material from a small number of superior sires to a large number of females possible, but the success of an AI program depends on the proper management of semen collection, storage and use (Leboeuf et al., 2000; Petruska et al., 2014).

The viability, motility and membrane integrity of mammalian spermatozoa decrease during the cryopreservation process and cold shock could damage mitochondria (Pena et al., 2009), and plasma and acrosome membranes of spermatozoa (Meyers, 2005). During cryopreservation, the cell is exposed to several stresses which can result in compromised its function and death (Smith et al., 2011). Also, spermatozoa were exposed to cold shock and atmospheric oxygen, which in turn increases their susceptibility to lipid peroxidation (LPO) due to higher production of reactive oxygen species (ROS) (Nair et al., 2006).

ROS and antioxidants have been shown to play an important role in male fertility. The frozen-thawed spermatozoon produce ROS due to cellular respiration several evidences suggested reduction in antioxidant levels in seminal plasma and hence they are sensitive to oxidative damage induced by high $\mathrm{O} 2$ concentrations. Also, the high content of unsaturated fatty acids in the phospholipids of sperm plasma membrane increased the peroxidative damage (Lenzi et al., 2002; Nair et al., 2006). The excessive formation of both ROS and LPO during sperm cryopreservation has been associated with a decrease in quality, viability and fertilizing potential of thawed spermatozoa (Asadpour et al., 2012). Thus, addition of synthetic antioxidants to semen extenders could reduce the impact of oxidative stress during the sperm storage process, and led to improve the quality of cryopreserved semen. In general, antioxidants are compounds that dispose of scavenge and suppress the formation of the toxicity of ROS such as $\mathrm{H}_{2} \mathrm{O}_{2}$ and LPO to the viability and fertilizing potential of bovine spermatozoa (Folstad and Skarstein, 1997).

Coenzyme Q10 (CoQ10), known as ubiquinone or ubidecarenone, is a lipophilic molecule classified as a fat soluble quinine (Kapoor and Kapoor, 2013) presented in all cellular membranes and in blood (Pîndaru et al. 2015). CoQ10 plays an important role in cellular metabolism. It is an important lipid-soluble antioxidant, scavenges free radicals and inhibits oxidation of lipid as well as a membrane stabilizer (ElTohamy et al. 2012). It is also play a key role in the mitochondrial electron transport chain as a coenzyme in adenosine triphosphate (ATP) synthesis (Showell et al., 2011). The highest CoQ10 concentrations were found in organs with the highest energy requirements such as the heart and the liver (Dos Santos et al., 2009).

In sperm cells, most CoQ10 is concentrated in the mitochondria of the mid- piece and there is a direct correlation between its levels in seminal fluid and sperm characteristics. Also, energy of the sperm cell depends on the availability of CoQ10 (Mancini et al., 2005). CoQ10 is commonly used to enhance sperm motility in human due to its protective effects against LPO and DNA fragmentation of cryopreserved spermatozoa (Showell et al., 2011; Talevi et al., 2013).

Therefore, the current study was undertaken to investigate the effect of extender supplementation with Coenzyme Q10 (20 and $30 \mu \mathrm{M})$ on sperm quality and viability following the freeze-thawing process of both Egyptian buffalo and cattle bulls semen. 


\section{MATERIALS AND METHODS}

The present study was conducted at Animal Production Research Station, El-Gemmezah, belonging to Animal Production Research Institute, Agricultural Research Center, Ministry of Agriculture Egypt. Animals and semen collection:

Semen was collected, twice weekly for 5 weeks, from five sexually mature Egyptian buffalo (4 years old and 400-450 kg LBW) and Friesian bulls (3 years old and $350-400 \mathrm{~kg} \mathrm{LBW}$ ) using an artificial vagina (IMV, France) at 7-8 a.m. After collection, ejaculates were taken immediately to the laboratory in water bath at $37^{\circ} \mathrm{C}$ for evaluation and freezing processes. Only ejaculates with mass motility $\geq 70 \%$ on day of semen collection were evaluated. All ejaculates were pooled and divided into three portions diluted with Tris extender supplemented with 2 levels of CoQ10 (C9538: Sigma Aldrich co., St Louis, Mo, USA) and control without supplementation.

Experimental semen extenders:

Semen was extended in Tris-egg yolk extender (Tris, $0.325 \mathrm{~g}$; citric acid, $1.675 \mathrm{~g}$; glucose, $0.75 \mathrm{~g}$; streptomycin, $0.005 \mathrm{~g}$ and lincomycin, $0.25 \mathrm{~g}$ in $100 \mathrm{ml}$ distilled water, then $10 \%$ egg yolk and $7 \%$ glycerol were added to $83 \mathrm{ml}$ Tris extender). The dilution rate was 1:10. Three types of extenders were used, T1 without supplementation (control), T2 (with $20 \mu \mathrm{M}$ of CoQ10) and T3 (30 $\mu \mathrm{M}$ of CoQ10).

Semen processing:

Diluted semen was aspirated into medium-sized $(0.25 \mathrm{ml})$ French straws, sealed with polyvinyl alcohol powder and equilibrated at $5^{0} \mathrm{C}$ for $4 \mathrm{~h}$. After equilibration, the straws were frozen in liquid nitrogen vapor, $5 \mathrm{~cm}$ above liquid nitrogen for $10 \mathrm{~min}$ and then the straws were plunged into liquid nitrogen for storage $\left(-196^{\circ} \mathrm{C}\right)$. After storage for 4 weeks, frozen straws were thawed at $37^{0} \mathrm{C}$ for $30 \mathrm{~s}$ in water bath.
Semen evaluation and enzyme activity:Semen extended with each treatment level was evaluated in post-diluted, post-equilibrated and post-thawed semen (at $37^{\circ} \mathrm{C}$ for $30 \mathrm{~s}$ ) for percentage of individual motility, livability, abnormality, acrosomal damage and curled tail spermatozoa. Percentage of curled spermatozoa (HOS-t) was performed at $50 \mathrm{mOsm} / 1$ for $30 \mathrm{~min}$.

Also, enzyme activities of asprtate (AST), alanine (ALT) transaminases (Schmidt and Schmidt, 1963) and lactic dehydrogenase, LDH (Howell and Cols, 1979) ) were determined in seminal plasma of post-thawed semen.

Statistical analysis:

Data were statistically analyzed by the methods of analysis of variance according model procedures of SPSS (2013) to test the effect of species, antioxidant treatment or their interaction on different sperm characteristics of enzyme activity. Duncan multiple rang test was used to test the significant differences among means (Duncan, 1955). The percentage values were subjected to arcsine transformation before performing the analysis of variance. Means were presented after being recalculated from the transformed values to percentages. All mean differences were set at $\mathrm{P}<0.05$.

\section{RESULTS}

\section{Sperm characteristics in post-diluted semen:}

Sperm characteristics including percentages of motility, livability, abnormality, curled tail and damage acrosome in post-diluted semen, were not affected significantly by animal species. However, the effect of CoQ10 treatment was significant $(\mathrm{P}<0.05)$ on all sperm characteristics studied, being significantly $(\mathrm{P}<0.05)$ better in semen extended with both CoQ10 levels than control one. It is of interest to not that increasing level of CoQ10 from 20 to $30 \mu \mathrm{M}$ significantly $(\mathrm{P}<0.05)$ improved all sperm characteristics in diluted semen. There was no significant effect of interaction between animal species and different CoQ10 levels on all sperm characteristics (Table 1).

Table 1. Mean and standard error of sperm characteristics in post-diluted semen as affected by species, CoQ10 treatment and their interaction.

\begin{tabular}{|c|c|c|c|c|c|}
\hline \multirow{2}{*}{ Item } & \multirow[b]{2}{*}{ Sperm motility } & \multicolumn{3}{|c|}{ Sperm characteristics $(\%)$} & \multirow[b]{2}{*}{$\begin{array}{c}\text { Damage } \\
\text { acrosome }\end{array}$} \\
\hline & & $\begin{array}{l}\text { Sperm } \\
\text { livability }\end{array}$ & $\begin{array}{c}\text { Sperm } \\
\text { abnormality }\end{array}$ & $\begin{array}{c}\text { Curled } \\
\text { spermatozoa }\end{array}$ & \\
\hline \multicolumn{6}{|l|}{ Effect of species: } \\
\hline Buffalo (B) & $72.87 \pm 1.24$ & $71.53 \pm 1.28$ & $19.33 \pm 1.75$ & $71.87 \pm 0.96$ & $19.80 \pm 1.10$ \\
\hline Cattle (C) & $73.60 \pm 1.22$ & $72.27 \pm 1.54$ & $20.20 \pm 1.78$ & $73.47 \pm 1.06$ & $20.67 \pm 1.09$ \\
\hline Significance & $\mathrm{P}<0.42^{\mathrm{NS}}$ & $\mathrm{P}<0.43^{\mathrm{Ns}}$ & $\mathrm{P}<0.34^{\mathrm{NS}}$ & $\mathrm{P}<0.12^{\mathrm{NS}}$ & $\mathrm{P}<0.11^{\mathrm{NS}}$ \\
\hline \multicolumn{6}{|c|}{ Effect of antioxidant treatment: } \\
\hline T1 (control) & $67.70 \pm 0.79^{c}$ & $65.90 \pm 0.72^{\mathrm{c}}$ & $28.20 \pm 1.01^{\mathrm{a}}$ & $69.00 \pm 0.79^{c}$ & $25.50 \pm 0.48^{\mathrm{a}}$ \\
\hline $\mathrm{T} 2(20 \mu \mathrm{M}$ CoQ10) & $74.80 \pm 0.77^{\mathrm{b}}$ & $72.20 \pm 0.53^{\mathrm{b}}$ & $17.70 \pm 0.70^{\mathrm{b}}$ & $73.00 \pm 0.77^{\mathrm{b}}$ & $18.90 \pm 0.57^{\mathrm{b}}$ \\
\hline T3 (30 $\mu \mathrm{M}$ CoQ10) & $77.20 \pm 0.70^{\mathrm{a}}$ & $77.60 \pm 0.98^{\mathrm{a}}$ & $13.40 \pm 0.43^{\mathrm{c}}$ & $76.00 \pm 1.00^{\mathrm{a}}$ & $16.30 \pm 0.37^{\mathrm{c}}$ \\
\hline \multicolumn{6}{|l|}{ Effect of interaction: } \\
\hline T1x B & $67.00 \pm 1.22$ & $65.80 \pm 0.49$ & $28.00 \pm 1.26$ & $68.40 \pm 0.81$ & $25.40 \pm 0.40$ \\
\hline T1x C & $68.40 \pm 1.03$ & $66.00 \pm 1.45$ & $28.40 \pm 1.72$ & $69.60 \pm 1.40$ & $25.60 \pm 0.93$ \\
\hline $\mathrm{T} 2 \times \mathrm{B}$ & $74.60 \pm 0.40$ & $72.00 \pm 0.89$ & $16.80 \pm 0.58$ & $72.20 \pm 0.97$ & $17.80 \pm 0.37$ \\
\hline $\mathrm{T} 2 \times \mathrm{C}$ & $75.00 \pm 1.58$ & $72.40 \pm 0.68$ & $18.60 \pm 1.21$ & $73.80 \pm 1.20$ & $20.00 \pm 0.84$ \\
\hline $\mathrm{T} 3 \times \mathrm{B}$ & $77.00 \pm 0.95$ & $76.80 \pm 0.97$ & $13.20 \pm 0.58$ & $75.00 \pm 1.58$ & $16.20 \pm 0.58$ \\
\hline $\mathrm{T} 3 \times \mathrm{C}$ & $77.40 \pm 1.12$ & $78.40 \pm 1.75$ & $13.60 \pm 0.68$ & $77.00 \pm 1.22$ & $16.40 \pm 0.51$ \\
\hline Significance & $\mathrm{P}<0.87^{\mathrm{NS}}$ & $\mathrm{P}<0.79^{\mathrm{NS}}$ & $\mathrm{P}<0.76^{\mathrm{NS}}$ & $\mathrm{P}<0.95^{\mathrm{NS}}$ & $\mathrm{P}<0.21^{\mathrm{NS}}$ \\
\hline
\end{tabular}


Sperm characteristics in post-equilibrated semen:

As found in post-diluted semen, all sperm characteristics in post-equilibrated semen were not affected significantly by animal species, but were affected significantly by $30 \mu \mathrm{M}$ CoQ 10 , followed by 20 $\mu \mathrm{M}$ CoQ10, and the lowest for control (unsupplemented). Percentage of sperm motility and curled tail spermatozoa was significantly $(\mathrm{P}<0.05)$ better in semen extended with both CoQ10 levels than control one. However, percentage of livability, abnormality and damage acrosome of spermatozoa was significantly $(\mathrm{P}<0.05)$ the highest for semen extended with $30 \mu \mathrm{M}$ CoQ10. There was no significant effect of interaction between animal species and different CoQ10 levels on all sperm characteristics (Table 2).

Table 2. Mean and standard error of sperm characteristics in post- equilibrated semen as affected by species, CoQ10 treatment and their interaction.

\begin{tabular}{|c|c|c|c|c|c|}
\hline \multirow[b]{2}{*}{ Item } & \multicolumn{5}{|c|}{ Sperm characteristics (\%) } \\
\hline & $\begin{array}{l}\text { Sperm } \\
\text { motility }\end{array}$ & Sperm livability & $\begin{array}{c}\text { Sperm } \\
\text { abnormality }\end{array}$ & $\begin{array}{c}\text { Curled } \\
\text { spermatozoa }\end{array}$ & $\begin{array}{c}\text { Damage } \\
\text { acrosome }\end{array}$ \\
\hline \multicolumn{6}{|l|}{ Effect of species } \\
\hline Buffalo (B) & $68.47 \pm 1.43$ & $68.60 \pm 1.67$ & $23.93 \pm 1.89$ & $69.80 \pm 1.40$ & $23.67 \pm 1.36$ \\
\hline Cattle (C) & $69.33 \pm 1.48$ & $69.13 \pm 1.66$ & $24.87 \pm 1.86$ & $70.67 \pm 1.30$ & $24.20 \pm 1.37$ \\
\hline Significance & $\mathrm{P}<0.36^{\mathrm{NS}}$ & $\mathrm{P}<0.60^{\mathrm{NS}}$ & $\mathrm{P}<0.19^{\mathrm{NS}}$ & $\mathrm{P}<0.42^{\mathrm{NS}}$ & $\mathrm{P}<0.34^{\mathrm{NS}}$ \\
\hline \multicolumn{6}{|l|}{ Effect of treatment } \\
\hline T1 (control) & $62.00 \pm 0.76^{\mathrm{b}}$ & $62.00 \pm 0.56^{\mathrm{c}}$ & $33.80 \pm 0.73^{\mathrm{a}}$ & $64.20 \pm 1.25^{\mathrm{b}}$ & $30.60 \pm 0.60^{\mathrm{a}}$ \\
\hline $\mathrm{T} 2(20 \mu \mathrm{M}$ CoQ10) & $71.50 \pm 0.78^{\mathrm{a}}$ & $68.60 \pm 0.52^{b}$ & $21.50 \pm 0.54^{\mathrm{b}}$ & $72.60 \pm 0.73^{\mathrm{a}}$ & $22.40 \pm 0.40^{\mathrm{b}}$ \\
\hline T3 (30 $\mu \mathrm{M}$ CoQ10) & $73.20 \pm 0.80^{\mathrm{a}}$ & $76.00 \pm 1.21^{\mathrm{a}}$ & $17.90 \pm 0.50^{\mathrm{c}}$ & $73.90 \pm 0.57^{\mathrm{a}}$ & $18.80 \pm 0.33^{\mathrm{c}}$ \\
\hline \multicolumn{6}{|l|}{ Effect of interaction } \\
\hline T1x B & $61.80 \pm 1.11$ & $61.80 \pm 0.80$ & $33.60 \pm 0.98$ & $63.60 \pm 1.86$ & $30.40 \pm 0.68$ \\
\hline T1x C & $62.20 \pm 1.16$ & $62.20 \pm 0.86$ & $34.00 \pm 1.18$ & $64.80 \pm 1.83$ & $30.80 \pm 1.07$ \\
\hline $\mathrm{T} 2 \times \mathrm{B}$ & $70.80 \pm 1.07$ & $68.20 \pm 0.97$ & $20.40 \pm 0.40$ & $72.60 \pm 1.33$ & $22.00 \pm 0.71$ \\
\hline $\mathrm{T} 2 \times \mathrm{C}$ & $72.20 \pm 1.16$ & $69.00 \pm 0.45$ & $22.60 \pm 0.75$ & $72.58 \pm 0.81$ & $22.80 \pm 0.37$ \\
\hline T3 x B & $72.80 \pm 1.36$ & $75.80 \pm 1.77$ & $17.80 \pm 0.80$ & $73.20 \pm 0.92$ & $18.60 \pm 0.51$ \\
\hline $\mathrm{T} 3 \times \mathrm{C}$ & $73.60 \pm 0.98$ & $76.20 \pm 1.85$ & $18.00 \pm 0.71$ & $74.60 \pm 0.60$ & $19.00 \pm 0.45$ \\
\hline Significance & $\mathrm{P}<0.91^{\mathrm{NS}}$ & $\mathrm{P}<0.98^{\mathrm{NS}}$ & $\mathrm{P}<0.44^{\mathrm{NS}}$ & $\mathrm{P}<0.84^{\mathrm{NS}}$ & $\mathrm{P}<0.94^{\mathrm{NS}}$ \\
\hline
\end{tabular}

Means denoted within the same column with different superscripts are significantly different at $P<0.05$. ${ }^{\text {NS }}$ : Not significant.

Sperm characteristics in post-thawed semen:

Finally, in post-thawed semen, percentages of abnormality, livability, curled tail spermatozoa were not affected significantly by animal species, but each of sperm abnormality and damage acrosome spermatozoa were significantly $(\mathrm{P}<0.01)$ higher in cattle than in buffalo post-thawed semen. However, the effect of CoQ10 treatment was significant $(\mathrm{P}<0.05)$ on all sperm characteristics studied, being significantly $(\mathrm{P}<0.05)$ the highest in semen extended with $30 \mu \mathrm{M}$ CoQ10, ranked the second for that extended with $20 \mu \mathrm{M}$ CoQ10, while the lowest in control semen. Effect of interaction between animal species and different CoQ10 levels was significant only on sperm abnormality $(\mathrm{P}<0.01)$ and damage acrosome $(\mathrm{P}<0.05)$ spermatozoa. This effect was reflected in similar trend of lower percentages of sperm abnormality and damage acrosome spermatozoa in buffalo than in cattle post-thawed semen for each treatment, being the lowest in post-thawed buffalo semen extended with CoQ10 at a level of $30 \mu \mathrm{M}$ (Table 3).

Table 3. Mean and standard error of sperm characteristics in post-thawed semen as affected by species, CoQ10 treatment and their interaction.

\begin{tabular}{|c|c|c|c|c|c|}
\hline \multirow{2}{*}{ Item } & \multicolumn{5}{|c|}{ Sperm characteristics $(\%)$} \\
\hline & $\begin{array}{c}\text { Sperm } \\
\text { motility }\end{array}$ & Sperm livability & $\begin{array}{c}\text { Sperm } \\
\text { abnormality }\end{array}$ & $\begin{array}{c}\text { Curled } \\
\text { spermatozoa }\end{array}$ & $\begin{array}{c}\text { Damage } \\
\text { acrosome }\end{array}$ \\
\hline \multicolumn{6}{|l|}{ Effect of species } \\
\hline Buffalo (B) & $55.93 \pm 2.01$ & $61.33 \pm 1.76$ & $29.93 \pm 2.00$ & $63.33 \pm 1.47$ & $28.47 \pm 1.72$ \\
\hline Cattle (C) & $56.40 \pm 2.13$ & $61.87 \pm 1.72$ & $32.67 \pm 2.85$ & $63.07 \pm 1.36$ & $32.80 \pm 2.82$ \\
\hline Significance & $\mathrm{P}<0.68^{\mathrm{NS}}$ & $\mathrm{P}<0.67^{\mathrm{NS}}$ & $\mathrm{P}<0.007 * *$ & $\mathrm{P}<0.78^{\mathrm{NS}}$ & $\mathrm{P}<0.002 * *$ \\
\hline \multicolumn{6}{|l|}{ Effect of treatment } \\
\hline T1 (control) & $48.20 \pm 0.55^{\mathrm{c}}$ & $54.00 \pm 1.17^{\mathrm{c}}$ & $43.40 \pm 1.59^{\mathrm{a}}$ & $56.70 \pm 0.93^{\mathrm{c}}$ & $41.60 \pm 2.15^{\mathrm{a}}$ \\
\hline $\mathrm{T} 2(20 \mu \mathrm{M}$ CoQ10) & $54.40 \pm 1.18^{\mathrm{b}}$ & $62.40 \pm 0.62^{\mathrm{b}}$ & $27.80 \pm 0.55^{\mathrm{b}}$ & $65.00 \pm 0.83^{\mathrm{b}}$ & $27.40 \pm 0.62^{\mathrm{b}}$ \\
\hline $\mathrm{T} 3(30 \mu \mathrm{M}$ CoQ10) & $65.80 \pm 0.33^{\mathrm{a}}$ & $68.30 \pm 0.86^{\mathrm{a}}$ & $22.70 \pm 0.62^{c}$ & $67.90 \pm 0.55^{\mathrm{a}}$ & $22.90 \pm 0.94^{\mathrm{c}}$ \\
\hline \multicolumn{6}{|l|}{ Effect of interaction } \\
\hline $\mathrm{T} 1 \mathrm{x} \mathrm{B}$ & $48.00 \pm 0.89$ & $53.60 \pm 1.86$ & $39.80 \pm 0.66$ & $56.40 \pm 1.50$ & $36.80 \pm 0.97$ \\
\hline $\mathrm{T} 1 \mathrm{x} \mathrm{C}$ & $48.40 \pm 0.75$ & $54.40 \pm 1.63$ & $47.00 \pm 2.10$ & $57.00 \pm 1.26$ & $46.40 \pm 2.89$ \\
\hline $\mathrm{T} 2 \times \mathrm{B}$ & $54.00 \pm 0.55$ & $62.40 \pm 0.93$ & $27.60 \pm 0.93$ & $65.80 \pm 1.16$ & $26.20 \pm 0.66$ \\
\hline $\mathrm{T} 2 \times \mathrm{C}$ & $54.80 \pm 2.42$ & $62.60 \pm 1.32$ & $28.00 \pm 0.71$ & $64.20 \pm 1.20$ & $28.60 \pm 0.75$ \\
\hline $\mathrm{T} 3 \times \mathrm{B}$ & $65.80 \pm 0.49$ & $68.00 \pm 1.38$ & $22.40 \pm 1.08$ & $67.80 \pm 0.80$ & $22.40 \pm 1.36$ \\
\hline $\mathrm{T} 3 \times \mathrm{C}$ & $66.00 \pm 1.30$ & $68.60 \pm 1.17$ & $23.00 \pm 0.71$ & $68.00 \pm 0.84$ & $23.40 \pm 1.40$ \\
\hline Significance & $\mathrm{P}<0.94^{\mathrm{NS}}$ & $\mathrm{P}<0.95^{\mathrm{NS}}$ & $\mathrm{P}<0.009 * *$ & $\mathrm{P}<0.60^{\mathrm{NS}}$ & $\mathrm{P}<0.02 *$ \\
\hline
\end{tabular}

Means denoted within the same column with different superscripts are significantly different at $P<0.05$.

NS: Not significant. * Significant at $\mathbf{P}<0.05$. ** Significant at $\mathbf{P}<0.01$. 
Enzyme activity in seminal plasma of post-thawed semen:

In seminal plasma of post-thawed semen, activity of transaminases (AST and ALT) was significantly $(\mathrm{P}<0.001)$ affected by animal species, being higher in buffalo than in cattle semen. However, LDH activity was not affected significantly by animal species. Meanwhile, effect of CoQ10 treatment was significant $(\mathrm{P}<0.05)$ on all enzyme activities. Extension of semen with both levels significantly $(\mathrm{P}<0.05)$ reduced all enzyme activities, showing marked reduction by increasing level of CoQ10 from 20 to 30, except for AST activity. Effect of interaction between animal species and different CoQ10 levels on all enzyme activities was not significant (Table 4).

Table 4. Mean and standard error of AST, ALT and LDH in seminal plasma of post-thawed semen as affected by species, CoQ10 treatment and their interaction.

\begin{tabular}{|c|c|}
\hline \multirow[t]{2}{*}{ Item } & Enzyme activity (IU/l) \\
\hline & LDH \\
\hline \multicolumn{2}{|c|}{ Effect of species } \\
\hline Buffalo (B) & $35.06 \pm 2.1930 .66 \pm 1.34268 .87 \pm 11.76$ \\
\hline Cattle (C) & $28.47 \pm 2.32 \quad 22.33 \pm 1.43 \quad 259.20 \pm 12.00$ \\
\hline Significance & $\mathrm{P}<0.00 * * * \quad \mathrm{P}<0.00 * * *$ \\
\hline \multicolumn{2}{|c|}{ Effect of treatment } \\
\hline $\mathrm{T} 1$ (control) & $43.20 \pm 1.36^{\mathrm{b}} 32.80 \pm 1.50^{\mathrm{c}} 319.90 \pm 6.71^{\mathrm{c}}$ \\
\hline $\mathrm{T} 2(20 \mu \mathrm{M} \mathrm{C}$ & $27.00 \pm 1.22^{\mathrm{a}} 25.00 \pm 1.59^{\mathrm{b}} 252.50 \pm 4.47^{\mathrm{b}}$ \\
\hline $\mathrm{T} 3(30 \mu \mathrm{M} \mathrm{C}$ & $25.10 \pm 1.44^{\mathrm{a}} 21.70 \pm 1.65^{\mathrm{a}} 219.70 \pm 4.67^{\mathrm{a}}$ \\
\hline \multicolumn{2}{|c|}{ Effect of interaction } \\
\hline $\mathrm{T} 1 \mathrm{x} \mathrm{B}$ & $46.20 \pm 1.20 \quad 36.80 \pm 1.02 \quad 324.39 \pm 9.80$ \\
\hline $\mathrm{T} 1 \mathrm{x} \mathrm{C}$ & $40.20 \pm 1.5628 .80 \pm 1.07 \quad 315.40 \pm 9.81$ \\
\hline $\mathrm{T} 2 \times \mathrm{B}$ & $30.20 \pm 1.07 \quad 29.00 \pm 1.30 \quad 257.80 \pm 4.35$ \\
\hline $\mathrm{T} 2 \times \mathrm{C}$ & $23.80 \pm 0.66 \quad 21.00 \pm 1.29 \quad 247.20 \pm 7.55$ \\
\hline T3 $\times$ B & $28.80 \pm 1.1126 .20 \pm 1.06 \quad 224.40 \pm 6.49$ \\
\hline $\mathrm{T} 3 \times \mathrm{C}$ & $21.40 \pm 1.12 \quad 17.20 \pm 1.02 \quad 215.00 \pm 6.71$ \\
\hline Significance & $\mathrm{P}<0.82^{\text {NS }} \quad \mathrm{P}<0.88^{\mathrm{NS}}$ \\
\hline
\end{tabular}

Means denoted within the same raw with different superscripts are significantly different at $\mathbf{P}<0.001$.

AST asprtate transaminases; ALT: alanine transaminases; LDH: lactic dehydrogenase.

${ }^{N S}$ : Not significant. $* * *$ Significant at $\mathbf{P}<0.001$

\section{DISCUSSION}

Artificial insemination (AI) is an essential tool for increasing genetic improvement. Semen cryopreservation is an effective way with various advantages to the livestock industry (Bucak et al., 2009). Using AI of cryopreserved semen leads dissemination of genetic material from a small number of superior sires to a large number of females (Petruska et al., 2014). Distribution of high genetic merit frozen semen to livestock holders need more research to deliver healthy motile life sperm. This target will be achieved by using much more protective cryopreservation media.

The current study aimed to evaluate the freezability of buffalo and cattle semen as affected by supplementing Tris-extender with Coenzyme Q10 at levels of 20 or $30 \mu \mathrm{M}$, in terms of motility, livability, abnormality, curled tail and damage acrosome of spermatozoa during dilution, equilibration and thawing of semen. In general, the obtained results in our study indicated species differences only in post-thawed semen for percentages of sperm abnormality and damage acrosome spermatozoa only, being significantly $(\mathrm{P}<0.01)$ higher in cattle than in buffalo, but percentages of abnormality, livability, curled tail spermatozoa were not affected significantly by animal species. Increasing percentages of abnormality and damage acrosome in Friesian than in buffalo fresh semen was indicated by El-Sherbieny (2004). Similar trend of sperm abnormality percentage between both species was reported by Ghareeb (2003). However, an opposite trend was reported by El-Keraby et al. (1995) and Dandoush (2002), who reported insignificant differences in percentages of sperm abnormality and damage acrosome spermatozoa between Friesian and buffalo semen. The present results may indicate increasing morphological abnormalities of spermatozoa during freezing process in cattle as compared to buffalo semen, because species differences in all sperm characteristics was not significant in post-diluted and post-equilibrated semen.

During freezing processes, marked reduction in viability, livability and integrity of sperm membrane and acrosome, and subsequently increasing sperm morphological abnormalities (Meyers, 2005; Pena et al., 2009). During cryopreservation, the cell is exposed to several stresses which can result in compromised its function and death (Smith et al., 2011). Also, spermatozoa were exposed to cold shock and atmospheric oxygen, which in turn increases their susceptibility to lipid peroxidation due to higher production of reactive oxygen species (Nair et al., 2006). Excessive production of ROS in seminal plasma caused sperm immobilization by compromising their function through lipid peroxidation and DNA damage (Aitken et al., 2010). Also, ROS can diffuse across the membranes into the cells and inhibits the activity of some vital enzymes decrease the phosphorylation in axonemal protein. The present study indicated significant improvement in all sperm characteristics during dilution, equilibration and thawing under the effect of extension of semen with $30 \mu \mathrm{M}$ CoQ10, followed by $20 \mu \mathrm{M}$ CoQ10. In this line, several authors reported that CoQ10 has a bio-energetic and an antioxidant role by reducing mitochondrial ROS generation, stabilizing mitochondrial membrane potential and enhancing ATP production (Somayajulu et al., 2005; Mancini and Balercia, 2011). In vitro treatment of spermatozoa with CoQ10 preserves sperm motility avoids sperm lipid peroxidation and DNA fragmentation (Talevi et al., 2013). In addition, CoQ10 is the only lipid stable electron carrier in the mitochondrial electron transport system, which where most ROS are produced in the cell. The mitochondrial inner membrane contains CoQ10 and $\alpha$-tocopherol, both possessing antioxidant properties and acting in combination to scavenge free radicals during auto oxidation of mitochondrial membrane (Yousefian et al., 2014).Earlier studies (Page et al., 1961) established that the Coenzyme $\mathrm{Q}$ group had a recognized role with succlnoxidase in sperm cellular respiration and oxidative phosphorylation since ATP-ase and succinic 
dehydrogenase are associated with sperm motility. Hence, CoQ10 protect sperm membrane lipids against peroxidative damage, promotes membrane stability, scavenges superoxide anion and peroxides and plays an important role in sperm maturation and development (Agarwal and Prabakaran, 2005). CoQ10 supplementation to semen extender as an antioxidant significantly enhance total motility of cattle and buffalo sperm than the control group, especially after thawing, for $30 \mu \mathrm{M}$ CoQ10 enriched extender in T3. Our results are in agreement with (Talevi et al., 2013) that CoQ10 able to diminish the fierce effect of ROS on sperm mobility and acrosomal damage especially in postthawed semen. CoQ10 is able to scavenge free radicals that can cause damage to DNA proteins and lipids, base degradation of the DNA molecule and DNA fragmentation (Dos Santos et al., 2009; Gualtieri et al., 2014), consequently spermatozoa with damaged DNA lose their ability to fertilize the oocyte and consequently low conception rate (Agarwal and Prabakaran, 2005).

Improving incidence of acrosomal damage in the present study was associated with the lower activity of AST, ALT and LDH due to CoQ10 enrichment to extender of both species, being better for buffalo than cattle semen. Such results were supported by the theory that, good quality of semen characterized by lower activity of AST, ALT and LDH enzymes (Taha et al., 2000; El-Harairy et al., 2011), that could be due to lower injuries inflicted to cell membrane as evidenced by significantly lower total incidence of acrosomal changes (Borah et al. 2015).

\section{CONCLUSION}

The current study can conclude that CoQ10, as antioxidant, at a level of $30 \mu \mathrm{M}$ in Tris-extender is able to enhance most sperm characteristics including mobility, livability, plasma membrane integrity, decreasing sperm abnormalities and it is strong protective power against acrosomal damage of buffalo and cattle spermatozoa.

\section{REFERENCES}

Agarwal, A. and Prabakaran, A.S. (2005). Oxidative stress and antioxidants in male infertility: a difficult balance Iranian Journal of Reproductive Medicine Vol.3. No.1 pp: 1-8.

Aitken, R.J.; De Iuliis G.N.; Finnie J.M.; Hedges A. and McLachlan R.I. (2010). Analysis of the relationships between oxidative stress, DNA damage and sperm vitality in a patient population: development of diagnostic criteria. Hum Reprod., 25:2415-2426].

Asadpour, R.; Jafari, R. and Tayefi-Nasrabadi, H. (2012). The effect of antioxidant supplementation in semen extenders on semen quality and lipid peroxidation of chilled bull spermatozoa Iranian Journal of Veterinary Research, Shiraz University, Vol. 13, No. 3, Ser. No. 40.
Borah, S.; Xi L.; Zaug, A.J.; Powell, N.M.; Dancik, G.M.; Cohen, S.B.; Costello, J.C.; Theodorescu, D. and Cech, T.R. (2015). TERT promoter mutations and telomerase reactivation in urothelial cancer. Science, 347:1006-1010.

Bucak, M.N.; Tuncer, P.B.; Sariozkan, S. and Ulutas, P.A. (2009). Comparison of the effects of glutamine and an amino acid solution on postthawed ram sperm parameters, lipid peroxidation and antioxidant activities. Small Ruminant Res., 81: $13-17$.

Dandoush, S.I.S. (2002). Comparative studies on methods of evaluating semen quality in farm animals. M. Sc. Thesis, Fac. of Agric., Mansoura Univ., Egypt.

Dos Santos, G.C.; Antunes, L. M. G.; Dos Santos, A.C. and Bianchi, M.L.P. (2009). Coenzyme Q10 and its effects in the treatment of neurodegenerative diseases. Brazilian Journal of Pharmaceutical Sciences vol. 45, n. 4.

Duncan, D.B. (1955). Multiple Range and Multiple F. Test Biometrics., 11: 1-42.

El-Harairy, M.A.; Laila N. Eid; Zeidan, A.E.B.; Abd ElSalaam, A.M. and El-Kishk, M.A.M. (2011). Quality and fertility of the frozen-thawed bull semen as affected by the different cryoprotectants and glutathione levels. Journal of American Science, 7(5):791-801.

EL-Keraby, F.; Soheir, A. Fawzy and EL-Harairy, M.A. (1995). Comparative study of semen physical characteristics of Egyptian buffalo and Friesian bulls. J. Agric. Sci., Mansoura Univ., 20:3295.

El-Sherbieny, M.A. (2004): Physiological study on farm animals. Ph. D. Sc. Thesis Fac. Of Agric. Mansoura Univ. Egypt.

El-Tohamy, M.M., Kotp, M.S.; El-Nattat, W.S. and Mohamed, A.H. (2012). Semen characteristics and oxidative/antioxidative status in semen and serum of male rabbits supplemented with antioxidants during heat stress. Iran. J. Applied Anim. Sci., 2: 175-183.

Folstad, L. and Skarstein, F. (1997). Is male germ line control creating avenues for female choice. Behav. Ecol.; 8:109-112.

Ghareeb, W.S. (2003). Physiological studies on reproduction in cattle. Ph. D. Sc. Thesis Fac. Of Agric. Mansoura Univ. Egypt.

Gualtieri, R.; Barbato, V.; Fiorentino, I.; Braun, S.; Rizos, D.; Longobardi, S. and Talevi, R. (2014). Treatment with zinc, D-aspartate, and coenzyme Q10 protects bull sperm against damage and improves their ability to support embryo development. Theriogenology 82 592-598.

Howell, B.F. and Cols Clin. (1979). Chem. 25, 269.

Kapoor, P. and Kapoor, A.K. (2013). Coenzyme Q10-a novel molecule. J. Indian Acad. Clin. Med., 14: $37-45$.

Leboeuf, B.; Restall, B. and Salamon, S. (2000). Production and storage of goat semen for artificial insemination. Anim. Reprod. Sci., 62:113-141. 
Lenzi, A.; Gandini, L.; Lombardo, F.; Picardo, M.; Maresca, V. and Panfili, E. (2002). Polyunsaturated fatty acids of germ cell membranes, glutathione and glutathionedependent enzyme-PHGPx: from basic to clinic. Contraception. 65: 301-304.

Mancini, A. and Balercia, G. (2011). Coenzyme Q10 in male infertility: physiopathology and therapy. Biofactors, 37:374-380.

Mancini, A; Milardi, D.; Conte, G.; Festa, R.; De Marinis, L. and Littarru, G.P. (2005). Seminal antioxidants in humans: preoperative and postoperative evaluation of coenzyme Q10 in varicocele patients. Hormon Metab Res; 37: 428.

Meyers, S.A. (2005). Spermatozoa response to osmotic stress. Anim. Reprod. Sci., 89: 57-64.

Nair, J.S.; Brar, A.S.; Ahuja, C.C.; Sangha, S.P.S. and Chaudhary, K.C. (2006). A comparative study on lipid peroxidation, activities of antioxidant enzymes and viability of cattle and buffalo bull spermatozoa during storage at refrigeration temperature. Anim. Reprod. Sci., 96:21-29.

Page, Jr.A.C.; Smith, M.C.; Gale, P.H.; Polln, D. and Folkers, K. (1961). Coenzyme q. xxvi i 1. Activity of the coenzyme $q$ group in sperm motility. vol. 6 , no. 2 , biochemical and biophysical research communications.

Pena, F.J.; Rodriguez Martinez, H.; Tapia. J.A.; Ortega Ferrusola. C.; Gonzalez Fernandez, L. and Macias Garcia, B. (2009). Mitochondria in mammalian sperm physiology and pathology. A review, Reprod. Domest. Anim., 44: 345-349.

Petruska, P.; Capcarova, M. and Sutovsky, P. (2014). Antioxidant supplementation and purification of semen for improved artificial insemination in livestock species Turk. J. Vet. Anim. Sci. 38: 643-652.

Pîndaru, L.P.; Cenariu, M.; Pall, E. and Groza, I. Ș. (2015). Effects of coenzyme q10 on sperm viability during storage of boar semen at $17^{\circ} \mathrm{c}$. Scientific Works. Series C. Vet. Med. Vol. LXI (2)
S.P.S.S. (2013). SPSS user Guide: Statistics SPSS.

Schmidt, E. and Schmidt, F. W. (1963). Enzym. Biol. Clin. 3: 1 .

Showell, M.G.; Brown, J.; Yazdani, A.; Stankiewicz, M.T.; Hart, R.J. (2011). Antioxidants for male subfertility. Cochrane Database Syst Rev, Issue 1. Art.

Smith, G.D.; Motta, E.E. and Serafini, P. (2011). Theoretical and experimental basis of oocyte vitrification. Reprod Biomed Online. 23:298306.

Somayajulu, M.; McCarthy, S.; Hung, M.; Sikorska, M.; Borowy-Borowski, H. and Pandey, S. (2005). Role of mitochondria in neuronal cell death induced by oxidative stress; neuroprotection by Coenzyme Q10. Neurobiol. Dis., 618-627.

Taha, T.A.; Abdel-Gawad, E.I. and Ayoub, M.A. (2000). Monthly variations in some reproductive parameters of barki and awassi rams throughout 1 year under subtropical condition.2:Biochemical and enzymatic properties of seminal plasma. Anim. Sci., 71: 325.

Talevi, R.; Barbato, V.; Fiorentino, I.; Braun, S.; Longobardi, S. and Gualtieri, R. (2013). Protective effects of in vitro treatment with zinc, daspartate and coenzyme q10 on human sperm motility, lipid peroxidation and DNA fragmentation. Reproductive Biology and Endocrinology, 11:81

Yousefian, I.; Zare-Shahneh, A. and Zhandi, M. (2014). The Effect of Coenzyme Q10 and $\alpha$-Tocopherol in Skim Milk-Based Extender for Preservation of Caspian Stallion Semen in Cool Condition Journal of Equine Veterinary Science 34, 949954.

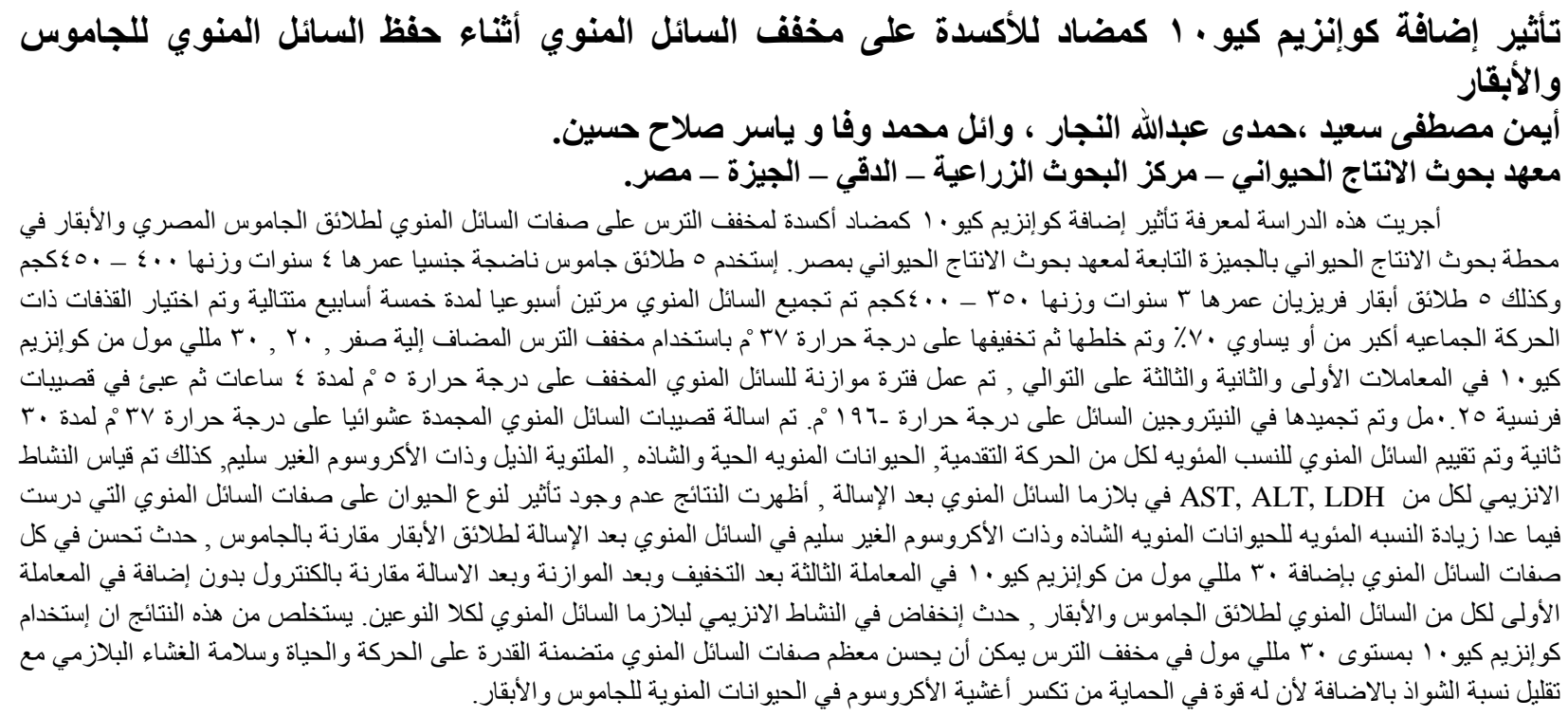

